\title{
Evaluation of Proficiency and Effectiveness of Occupational Health and Safety Education in Universities
}

\author{
Cihandar Hasanhanoglu \\ Occupational Health and Safety Program, Vocational School of Health Services, \\ Baskent University, Ankara, Turkey \\ E-mail: chasanhanoglu@baskent.edu.tr
}

\begin{abstract}
It is clear that educational studies to attain conscient, well informed and result oriented Occupational Health and Safety applications have been gaining more and more care and attention in our Country as well as the World. In this respect, it has become crucial to determine relevance and sufficiency of associate, undergraduate, post graduate and PHD programs in universities as of content and duration. It is doubtless that application of Occupational Health and Safety, a multidisciplinary field, to workplaces for achieving the prior objective and the ultimate result is only possible with educated manpower. In this respect, universities are significant actors as a driving force in shaping the safety culture. In this study, it is aimed to examine proficiency and effectiveness of Occupational Health and Safety Education with respect to professional competence and areic effectveness. It is also discussed compliance of the current education program to regulatory framework of our Country.
\end{abstract}

Key words: Occupational Health and Safety, Education, Programs.

DOI: $10.7176 / \mathrm{JSTR} / 5-7-12$

\section{Üniversitelerde İş Sağlığı ve Güvenliği Eğitimlerinin Yeterliliği ve Etkinliğinin Değerlendirilmesi}

\begin{abstract}
Özet
Özellikle son yıllarda dünyada olduğu gibi ülkemizde de dikkat çeken ve önemsenen iş sağllğı ve güvenliği faaliyetlerinin daha bilinçli, bilgili ve sonuç odaklı olması açısından eğitim çalışmalarının son derece önemli olduğu aşikârdır. Bu kapsamda üniversitelerde ön lisans, lisans, yüksek lisans ve doktora eğitim programlarının içerik ve süre açısından ne kadar uygun ve yeterli olduğunun tespiti önemlidir. Multidisipliner bir alan olan iş sağ lı̆̆ ve güvenliğinin nihai hedefe ve öncelikli amaca hizmet edecek şekilde işyerlerinde düzenlenmesi şüphesiz eğitilmiş insan gücü ile mümkündür. Bu kapsamda üniversiteler güvenlik kültürünün oluşturulması açısından itici güç ve önemli aktörlerin başında gelir. Söz konusu çalışmada; üniversitelerde iş sağlığı ve güvenliği eğitimlerinin yeterliliği ve etkinliğinin mesleki yeterlilik ve alansal etkinlik açısından incelenmesi amaçlanmıştır. Ülkemizde eğitim kurumlarınca verilmekte olan iş sağlığ 1 ve güvenliği eğitiminin, içeriği ve belirlenmiş olan mevzuata uygunluğu tartışılmıştır. Ülkemizdeki eğitim müfredatlarına katkı sağlayacak bir model önerisi getirilmiştir.
\end{abstract}

Anahtar kelimeler: İş sağlığı ve güvenliği, eğitim, programlar.

\section{GİRIŞ}

Çağdaş ve gelişmiş ülkelerde özellikle pozitif güvenlik kültürünün önemi ve bunun tüm toplumca kabul görmesi ve uygulanması sonucu iş kazaları ve meslek hastalıklarında ciddi düzeyde azalmalar olmuştur. Pozitif(olumlu) güvenlik kültürünün, karşılıklı güven üzerine kurulmuş iletişim, iş güvenliğinin önemine 
yönelik paylaşılan algılamalar ve önleyici tedbirlerin etkinliğine duyulan güven ile nitelendirilir. Güvenlik kültürü, sağlıklı ve güvenli davranışın bir alışkanlık haline getirilmesidir.

Örgüt kültürü ve örgüt iklimi birbiriyle ilişkili, ancak kültür, iklime göre daha somut bir kavramdır (Şişman,2002:156). Kültürel sistemler bir yandan davranışın ürünü, diğer yandan gelecekteki davranışın koşullayıcısıdır (Dursun, 2012. 14).

Güvenlik kültürünün oluşması ve olgunlaşmasında en önemli faktörlerden birisi de üniversitelerdir. Özellikle İSG alanında üniversitelere düșen önemli görevler olup, bunlar özetle;

$\checkmark \quad$ İsg - sosyal politikalara bilimsel katkı,

$\checkmark$ Güvenilir bir kayıt sistemi kurulmasına bilimsel altyapı,

$\checkmark$ İş kazalarının 'bilimsel' analizi,

$\checkmark$ İsg alanında çalışacak insan gücünün temel ve mesleki eğitimi,

$\checkmark$ İsg alanında çalışacak insan gücünün mezuniyet sonrası sürekli eğitimine katkı,

$\checkmark \quad$ İsg ile ilgili araştırmalar, laboratuvar çalışmaları,

$\checkmark$ İsg ile ilgili akademik ortam ve bilimsel çalışmalar şeklinde sıralamak mümkündür. Sorun İSG alanında ortaya konulan bu beklentilerin üniversitelerce yeterince karşılanıp karşılanamadığı sorunsalı tartışılmalıdır.

\section{AMAC ;}

Üniversitelerde yapılan iş sağlığı ve güvenliği eğitimlerinin yeterliliği ve etkinliği ortaya koymak ve özellikle yapılan eğitimlerinin program yeterlilik ve eğitim hedefleri ile ne kadar örtüştüğünü belirlemek bu konudaki eksiklik ve aksaklıkları belirlemektir.

\section{KAPSAM:}

Devlet ve vakıf üniversitelerine bağlı isg alanında eğitim ve öğretim faaliyetini sürdüren önlisans düzeyinde meslek yüksekokulları ile lisans, yüksek lisans ve doktora eğitimleri yapılan üniversitelerdeki programların ders içerikleri ile isg eğitim ve öğretimi kapsamında tespit edilen sorunlar ve çözüm önerileri olarak belirlenmiştir.

\section{YÖNTEM;}

Bu çalışmada nicel ve nitel metotlar birlikte kullanılmıştır. Özellikle Üniversitelerin İSG bölüm/ programlarına yönelik ders durumu kendi web sayfalarından alınarak analiz ve değerlendirmelerde kullanılmış, ayrıca sorunlara yönelik bizzat programlarda görevli bazı öğretim elemanlarının görüş ve önerilerinden yararlanılmıştır. Mevcut sorunları irdelemek ve incelemek üzere devlet ve vakıf üniversiteleri kapsamında örnek bazı üniversitelerin isg programları seçilerek incelemeye tabii tutulmuşlardır. Bu incelemede ülkemizin sosyal gelişmişlik ve ekonomik durumu ve bölgesel özellikleri gözetilerek 3 devlet,2 vakıf üniversitesinin isg önlisans programları, konu, kapsam, ders süreleri ve isg program yeterlilikleri açısından incelenmiştir. Programların incelenmesinde;

$\checkmark$ İSG açısından temel nitelikler ve yeterlilikler,

$\checkmark$ Mesleki tanımlama,

$\checkmark$ Görev ve ihtiyaç analizi,

$\checkmark$ Yasal mevzuatın belirlediği görev, yetki ve sorumluluklar

$\checkmark$ Programların nihai hedef ve yeterlilikleri ile program içeriği ve uyumluluğu göz önünde bulundurulmuştur

\section{2. İSG EĞITTiM VE ÖĞRENIMININ ÖNEMI;}

İş sağllğı ve güvenliği eğitimlerinin amac1; iş yerlerinde güvenli bir ortam meydana getirmek, iş kazalarını azaltmak ve çalışanlarda iş sağlığ 1 ve güvenliğine yönelik bilinç oluşturmak olarak özetlenebilir. Bu amaç doğrultusunda, ülkemizde üniversite ve kurum düzeyinde iş sağlığı ve güvenliği eğitimleri düzenlenmekte, ancak eğitimlerin içerik, süre, konu ve uygulama kapsamında istenen seviyeye ulaşılamadığ değerlendirilmektedir.

Dünya Sağlık Örgütü (WHO ) ve Uluslararası Çalışma Örgütü (ILO ) iş sağlığını, "çalışan tüm insanların fiziksel, ruhsal, moral ve sosyal yönden tam iyilik durumlarının sağlanmasını ve en yüksek düzeylerde sürdürülmesini, iş koşulları ve kullanılabilen zararlı maddeler nedeniyle çalışanların sağlığına gelebilecek zararların önlenebilmesi ve ayrıca işçinin fizyolojik özelliklerine uygun yerlere yerleştirilmesini işin insana ve insanın işe uymasını asıl amaçlar olarak ele alan tıp bilimidir." şeklinde tanımlamaktadır.(Gerek, 2012: 16).

İşyerlerini, işin yürütümü nedeniyle oluşan tehlikelerden ve sağlı̆̆a zarar verebilecek koşullardan arındırarak, daha iyi bir çalışma ortamı sağlamak için yapılan sistemli çalışmalar şeklinde tanımlanabilen 
iş güvenliği; hukuk, ekonomi, sosyal politika, davranış bilimleri, ergonomi, tıp, çeşitli mühendislik bilimleri, istatistik, matematik, sağlık bilimleri gibi disiplinlerden de yararlanmaktadır ( Gerek, 2012:17). Uluslararası çalışma örgütü (ILO ) 'nün tespitlerine göre kazalarının; yalnızca \%2 si korunması mümkün olmayan, geriye kalan \%98'i ise korunulması mümkün olanlar şeklindedir. Yine araştırmalarla; iş kazalarını \%50 'sinin kolaylıkla önlenebileceğinin ;\%48'inin sistemli bir çalışma ile önlenebileceğinin ,\%2 sinin ise önlenemeyeceğinin göstermektedir. Bir felaketinin önlemenin, ödemekten daha ucuz olduğu mantığından hareketle; işyerlerindeki tehlike kaynaklarını tespit ederek, bunlardan oluşabilecek riskleri önceden kontrol altına alıp; tehlikeli ortamları devre dışı bırakabiliriz. (Altınel, 2015)

Ülkemizde her altı dakikada bir iş kazası olmakta, her altı saatte bir çalışan ise hayatını kaybetmektedir Diğer taraftan istatistikler her 2.5 saatte bir iş̧̧inin iş göremez hale geldiğini de ortaya koymaktadır(Altınel,2015) .

Son 15 yılda (Tablo-1 ) 22308 çalışanın yaşamını yitirmesi gözönünde bulundurulduğunda sonuçlar çok vahim bir tablo olarak karşımıza çımaktadır.(TUIK:2018)

Bundan dolayıdır ki AB'nin Resmi İstatistik Ofisi Eurostat ve Sosyal Güvenlik Kurumu'nun (SGK) verilerine göre Türkiye iş kazalarında en fazla insanın hayatını kaybettiği ülkeler sıralamasında Avrupa'da ilk sırayı, dünyada ise üçüncü sıradaki yerimizi korumaya devam etmekteyiz ( 7,8$)$

İş sağ lığı ve güvenliğinin amacı, işyerlerinde iş sağlığı ve güvenliğinin sağlanması ve mevcut sağlık ve güvenlik şartlarının iyileştirilmesi için işveren ve çalışanlarının görev, yetki, sorumluluk, hak ve yükümlülüklerini düzenlemektir.(Şahingöz,A.,Şık,2015:14)

Tablo-1. 2003-2018 yılları arası iş kazaları sonucu yaşamını yitiren çalışan sayısı- kayıplar

\begin{tabular}{|c|c|c|c|c|c|}
\hline YIL & ÖL ̈̈ & YIL & ÖL ̈̈ & YIL & ÖL $̈$ \\
\hline 2003 & 810 & 2009 & 1071 & 2015 & 2041 \\
\hline 2004 & 841 & 2010 & 1454 & 2016 & 1970 \\
\hline 2005 & 1096 & 2011 & 1710 & 2017 & 2006 \\
\hline 2006 & 1601 & 2012 & 878 & 2018 & 1799 \\
\hline 2007 & 1044 & 2013 & 1235 & & \\
\hline 2008 & 866 & 2014 & 1886 & TOPLAM & $\mathbf{2 2 3 0 8}$ \\
\hline
\end{tabular}

$\mathrm{Bu}$ veriler ve çalışma yaşamı ile ilgili tespit edilen olumsuz koşullar değerlendirildiğinde, halen ülkemizde iş sağlığı ve güvenliğine yeterince önem gösterilmediği sonucunavulaşılabilir. Son yıllarla birlikte, iş sağlı̆̆ ve güvenliği ile ilgili yapılan hukuki düzenlemeler ve Ulusal yetkin kuruluşlar tarafindan yapılan çalışmalar sonucunda, iş sağlığı ve güvenliğine önem giderek artmaktadır. Yaşanan yetersizlikler ve aksaklıkların giderilmesi için sistemsel bütünlük içinde özellikle bu alanda etkili eğitim sistemine ve nitelikli insan gücüne ihtiyaç duyulmaya başlanmıştır. Bu konuda en önemli aktörlerin başında hiç şüphesiz üniversiteler gelmektedir. İSG alanında nitelikli eleman eksikliğini giderebilecek etkili eğitim sisteminin kurgulanıp program hedeflerinin gerçekleşip gerçekleşmediğinin araştırılması gereklidir.

İş sağlı̆̆ ve güvenliği eğitiminin amacı; iş yerlerinde güvenli bir ortam meydana getirmek, iş kazalarını azaltmak ve çalışanlarda iş sağlğ̆ ve güvenliğine yönelik bilinç oluşturmak olarak özetlenebilir.(Ceylan,2000) Bu amaç, 28648 sayılı 15. 05. 2013 tarihli resmi gazetede yayımlanan "Çalışanların İş Sağlığı ve Güvenliği Eğitimlerinin Usul ve Esasları Hakkında Yönetmelikte" belirtilmiştir. (10) Bu amaç doğrultusunda, ülkemizde üniversite ve kurum düzeyinde iş sağlığ 1 ve güvenliği eğitimleri düzenlenmekte, ancak eğitimlerin içerik, süre, konu ve uygulama kapsamında istenen seviyeye ulaşılamadığı görülmektedir.

\section{3. İSG ÖNLISANS EĞITTIMINDE TEMEL SORUNLAR;}

Ülkemizde verilmeye başlanan iş sağllğ̆ ve güvenliğgi alanındaki eğitimler, daha çok meslek yüksekokulları çerçevesinde verilmektedir. Aynı zamanda,2012 yılından itibaren lisans ve yüksek lisans/doktora programları da oluşturulmaya başlanmış ve halen bazı üniversitelerde aktif olarak eğitimler sürdürülmektedir. Ancak, ülkemizde halen iş sağlığı ve güvenliğgi alanında nitel ve nicel olarak eğitim eksikliği bulunmaktadır. İSG Ön Lisans programlarını bitiren adaylar iş sağlı̆̆ ve güvenliği teknikeri olarak mezun olmaktadırlar. İş sağlığı ve güvenliği hizmetlerinin uygulandığı tüm alanlarda teknik, hukuki, mesleki ve idari açıdan en iyi seviyeye yükseltilmesini amaçlayan bu programların nihai hedefi; mesleki açıdan yeterli teknik eleman yetiştirmek ve uygulama alanına teknik eleman desteği sağlamaktır.

İş sağlığı ve güvenliği ön lisans programı açılan üniversiteler ve açılma yerleri tablo2'de gösterilmiştir. Devlet ve vakıf üniversiteleri kapsamında örnek bazı üniversilerin İSG programları seçilerek incelemeye 
tabi tutulmuştur. $\mathrm{Bu}$ incelemede ülkemizin sosyal gelişmişlik ve ekonomik durumu ve bölgesel özellikleri gözetilerek 3 devlet (Kafkas Üniversitesi, Pamukkale, Üniversitesi Samsun Ondokuz Mayis Üniversitesi), 2 vakıf (Ankara Başkent Üniversitesi ve Istanbul Arel Üniversitesi) üniversitesinin İSG programları, konu, kapsam, ders süreleri ve İSG program yeterlilikleri açısından incelenmiştir.

Üniversitelerde önlisans isg eğitimleri kapsamında genelde tespit edilen temel sorunları şu şekilde özetlemek mümkündür.

$\checkmark \quad$ sektörel ihtiyaç, mesleki istihdam durumu gözetilmeksizin isg programının farklı bilim dalları altında açılması,

$\checkmark$ Bilimsel alan standartının belirsizliği ve farklılığı,

$\checkmark$ Programlarda nitelik sorunu ve ders standardizasyonun olamaması( çep belirsizliği )

$\checkmark \quad$ Öğretim elemanı yetersizliği,

$\checkmark$ Uygulama/ staj eğitimlerinde yaşanan sorunlar,

$\checkmark \quad$ Laboratuvar, atölye eksikliği şeklinde genel olarak sıralamak mümkündür.

Sorun-1. Sektörel ihtiyaç, mesleki istihdam durumu gözetilmeksizin isg programının farklı bilim dalları altında açılması;

Bugün ülkemizde 54 devlet 30 vakıf olmak üzere toplam 84 üniversiteye bağlı 100 meslek yüksekokulunda İSG eğitim programları açılmış olup, kontenjan doluluk oranı \%78 ile eğitim yapılmaktadır.

Ülkemizde 2018 yılı itibariyle sayıları yaklaşık 110948 ( 2018 yılı sonu itibariyle Türkiye genelinde; A sınıfı iş güvenliği uzmanı 17.677, B sınıfı iş güvenliği uzmanı 15518, C sınıfı iş güvenliği uzmanı ise 77753 ) bulan iş güvenliği uzmanlarının olduğu görülmektedir.(AÇSHB: 2018)

İş Güvenliği Uzmanlarına yönelik mesleki istihdam sorunu gözetilerek açılan programların sayı ve kontenjan durumu tekrar değerlendirilmesi gerekmektedir. Özellikle devlet ve vakıf üniversitelerine bağlı MYO'larının bölgesel dağılımı incelendiğinde, istihdam ve çalışma potansiyeli gözetilmeksizin program açılması dikkat çekicidir.

Tablo-2. ISG Programı açılan Üniversiteler ve bu üniversitelere bă̆lı MYO Çizelgesi, bölgesel dă̆llım

\begin{tabular}{|c|c|c|c|c|c|c|}
\hline Üniversiteler & $\begin{array}{c}\text { İG Prog. } \\
\text { Açılan } \\
\text { Üni. } \\
\text { Sayısı }\end{array}$ & $\begin{array}{c}\text { ISG } \\
\text { Prog. } \\
\text { Açılan } \\
\text { MYO }\end{array}$ & $\begin{array}{c}\text { MYO'ların bölgesel } \\
\text { dağılımı }\end{array}$ & $\begin{array}{c}\text { Devlet } \\
\text { üni. } \\
\text { MYO } \\
\text { oranı }\end{array}$ & $\begin{array}{c}\text { Vakıf } \\
\text { Üni. } \\
\text { MYO. } \\
\text { Oranı }\end{array}$ & $\begin{array}{c}\text { Genel } \\
\text { toplam }\end{array}$ \\
\hline Devlet Üni. & 54 & 70 & Akdeniz bölgesi & 6 & 2 & 8 \\
\hline Vakıf Üni. & 30 & 30 & Ege bölgesi & 9 & 2 & 11 \\
\hline & & & Karadeniz bölgesi & 19 & 1 & 20 \\
\hline & & & Marmara bölgesi & 12 & 22 & 34 \\
\hline & & & İç Ana. Bölgesi & 11 & 1 & 12 \\
\hline & & & Doğu Anadolu bölgesi & 9 & - & 9 \\
\hline & & & Güneydoğu Anadolu bölgesi & 4 & - & 4 \\
\hline & & & Kıbrı & - & 2 & 2 \\
\hline TOPLAM & $\mathbf{8 4}$ & $\mathbf{1 0 0}$ & & $\mathbf{7 0}$ & $\mathbf{3 0}$ & $\mathbf{1 0 0}$ \\
\hline
\end{tabular}

Tablo- 1. Üniversitelerin Meslek Yüksek Okul ISG programları Kontenjanlar ${ }^{7-8}$

\begin{tabular}{|c|c|c|c|c|c|c|}
\hline Yillar & $\begin{array}{c}\text { 1. Öğretim } \\
\text { Program } \\
\text { Sayısı }\end{array}$ & $\begin{array}{c}\text { 1. Öğgretim } \\
\text { Öğrenci } \\
\text { Sayısı }\end{array}$ & $\begin{array}{c}\text { 2. Öğretim } \\
\text { Program } \\
\text { Sayısı }\end{array}$ & $\begin{array}{c}\text { 2. Ö̈̆gretim } \\
\text { Ögrrenci } \\
\text { Sayıst }\end{array}$ & $\begin{array}{c}\text { Uzaktan } \\
\text { Ö̆̆gretim } \\
\text { Program Sayısı }\end{array}$ & $\begin{array}{c}\text { Uzaktan Ö̆ğretim } \\
\text { Ögrenci Sayısı }\end{array}$ \\
\hline 2010 & 9 & 385 & 4 & 180 & - & - \\
\hline 2011 & 8 & 345 & 3 & 150 & 1 & 50 \\
\hline 2012 & 16 & 700 & 7 & 380 & 1 & 50 \\
\hline 2013 & 18 & 950 & 10 & 500 & 2 & 250 \\
\hline 2014 & 34 & 1655 & 22 & 1080 & 5 & 600 \\
\hline 2015 & 34 & 1460 & 19 & 900 & 5 & 600 \\
\hline 2016 & 81 & 1955 & 39 & 1046 & 10 & 1541 \\
\hline 2017 & 99 & 5350 & 43 & 2297 & 11 & 3138 \\
\hline 2018 & 101 & 5846 & 47 & 2447 & 12 & 12255 \\
\hline
\end{tabular}


Sorun-2. Bilimsel Alan Standartının Belirsizliği ve Farklıı̆̆ı;

Aşağıdaki Tabloda görüleceği üzere Yüksekokullar bünyesinde 7 farklı alanda (Sağlık hizmetleri/ bilimleri, teknik, sosyal, güvenlik, hayvansal üretim gibi) iş sağlı̆̆ ve güvenliği programı düzenlenmiştir. İş sağlığ 1 ve güvenliği her ne kadar multi disipliner bir alan olsa bile sonuçta program standardizasyonu ve yaklaşım bütünlüğü açısından görülen dağınıklık dikkat çekici olup, program hedef ve profiline etki eden bilimsel alan yaklaşımındaki belirsizlik veya farklılı̆ıı giderilmesinin uygun olacağ değerlendirilmektedir.

Tablo-4. Yüksekokullar bilimsel alan dă̆ıllım çizelgesi

\begin{tabular}{|l|l|l|l|}
\hline Yüksekokulun adı & Alanı & Sayıs & \\
\hline Meslek yüksekokulu & Meslek & 75 & Muhtelif il ve ilçe mrk konuşlu \\
\hline Meslek Yüksekokulu & $\begin{array}{l}\text { Sağlık } \\
\text { hizmetleri. }\end{array}$ & 9 & Istanbul(5 ),Ankara(2 ),Trabzon,kıbrıs \\
\hline Meslek Yüksekokulu & Sağlı bilimleri. & 1 & Kıbrıs \\
\hline Meslek Yüksekokulu & Sosyal bilimler & 3 & Aksaray- Bingöl-istanbul- \\
\hline Meslek Yüksekokulu & Teknik bilimler & 10 & $\begin{array}{l}\text { Bayburt, Elazı̆, Corum, Karabük, } \\
\text { Karaman,Kilis,İstanbul,Niğde,Isparta,Bursa }\end{array}$ \\
\hline $\begin{array}{l}\text { Güvenlik Meslek } \\
\text { yüksekokulu }\end{array}$ & $\begin{array}{l}\text { Güvenlik } \\
\text { bilimleri }\end{array}$ & 1 & Van \\
\hline $\begin{array}{l}\text { Hayvansal Üretim ve } \\
\text { Yönetim Meslek } \\
\text { Yüksekokulu }\end{array}$ & $\begin{array}{l}\text { Hayvansal üre ve } \\
\text { yön. }\end{array}$ & 1 & Karabük-Eflani \\
\hline TOPLAM & $\mathbf{6}$ & $\mathbf{1 0 0}$ & \\
\hline
\end{tabular}

Sorun-3. Programlarda Nitelik Sorunu ve Ders Standardizasyonun Olamaması( çep belirsizliği ) İş sağlığı ve güvenliği hizmetlerinin uygulandığı tüm alanlarda teknik, hukuki, mesleki ve idari açıdan en iyi seviyeye yükseltilmesini amaçlayan bu programların nihai hedefi; mesleki açıdan yeterli teknik eleman yetiştirmek ve uygulama alanına teknik eleman desteği sağlamaktır.

İSG Teknikerlerinin görev tanımına bakacak olursak;

"İşletmelerde kullanılan makine, donanım ve ekipmanları tanıyan, bunların kullanımına ilişsin güvenlik tedbirleri hakkında yorum yapabilen, bireylerin sağlıklı ve güvenli bir iş ortamında çalışmalarına katkı sağlayan, 6331 sayılı iş sağlığı ve güvenliği kanunun kendisine tevdi ettiği görevleri yerine getirebilecek bilgi ve donanıma sahip meslek mensubudur " şeklinde tanımlanmaktadır. (Başkent Üni,) Kısacası meslek tanımı kapsamında beklentiler ile program hedef ve yeterliliğinin örtüşmesi ve program kazanımlarının mesleki beklentileri karşılaması öngörülmelidir.

Örnek olarak seçilen üniversitelerin ISG Programlarına yönelik hazırlanan Bilgi paket/sistemlerinde yer alan derslerin, mesleki görev tanımı ve alanı ile ilgili parametreler ile program içerik ve niteliği kapsamında ders uyumluluğu incelendiğinde;

Mesleki-alan derslerinin genel ders toplamı içindeki yerinin yaklaşı \%38-42 olduğu, seçmeli-destek dersleri ile ilgisiz veya kredi/akts doldurma amaçlı derslerin \%46- 48, YÖK kanunu kapsamında okutulması zorunlu derslerin ise \%10-16 oranında olduğu gerçeği program ve ders durumunun tekrar ele alınması sonucunu ortaya koymaktadır.

Tablo-5. Mesleki-alan derslerinin genel ders toplamı içindeki yeri

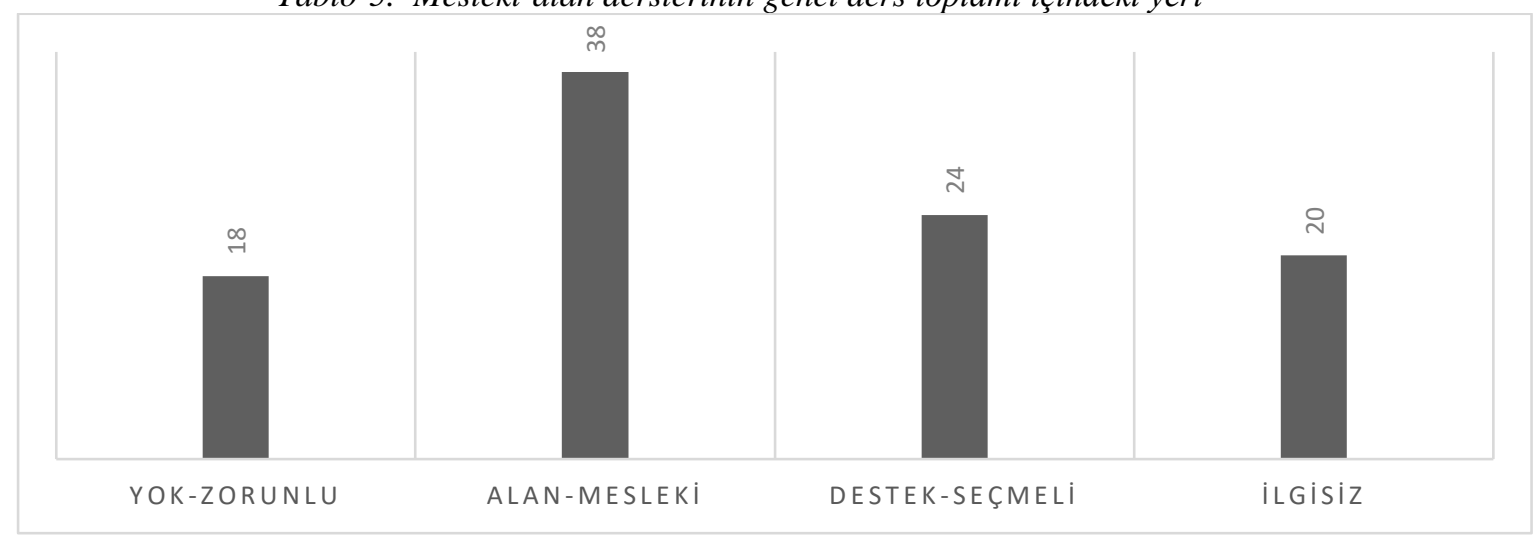


Mesleki yeterlilik ve görev tanım nitelikleri kapsamında çekirdek eğitim ve ders standardizasyonun da olmadığı görülmektedir. Ders programlarının isg 'nin nihai hedef ve öncelikli amacını sağlayacak şekilde düzenlenmediği, iş sağ lığı ve güvenliği konuları dışında, mesleki alan ile ilgisi olmayan, mesleki açıdan destek veya gelişimi sağlayıcı özelliği bulunmayan bazı derslerin de verilmekte olduğu görülmektedir. Özellikle verilen derslerin içeriğinin iş sağllğı ve güvenliği eğitimiyle birebir örtüşmediği de görülmektedir

Tablo-6. Programlarda tespit edilen dersler

\begin{tabular}{|c|c|c|}
\hline Konu alanları & Programlardaki ders durumu- 5 MYO İSG Programlarından alınan dersler & $\begin{array}{l}\text { Ders } \\
\text { Say1s1 }\end{array}$ \\
\hline $\begin{array}{l}\text { YÖK ORTAK } \\
\text { ZORUNLU }\end{array}$ & $\begin{array}{l}\text { Atatürk İlkeleri ve İnkılap Tarihi-I/II, İngilizce-I/II, Türk Dili-I/II,BTU,Güzel } \\
\text { Sanatlar,Ory }\end{array}$ & $\begin{array}{l}9-11 \\
\text { Ders }\end{array}$ \\
\hline $\begin{array}{l}\text { MESLEKİ } \\
\text { ALAN } \\
\text { DERSLERİ }\end{array}$ & $\begin{array}{l}\text { İş Sağlığı ve İş Güvenliği-I/II, Makine ve Teçhizat-I/II, İş Sağlığı ve Güvenliğgi } \\
\text { Hukuku, İş Hukuku, Genel Hukuk Bilgisi, İş Ve Sosyal Güvenlik Hukuku, İş } \\
\text { Güvenliği, Maden İşlerinde İSG, Yapı İşyerlerinde İSG, Ergonomi, İş Yerinde Risk } \\
\text { Analizi Ve Metotları, Kayıt ve Raporlama, Kimyasal Maddeler Ve Tehlikeleri, } \\
\text { Psikososyal Risk Etmenleri, Acil Durum Yönetimi, İSİG Yönetim Sistemi ve } \\
\text { Organizasyonu, İş Hijyeni, Taşıma ve Depolama, Yangın Ve Yangından Korunma, İş } \\
\text { Güvenliği İlkeleri, Çev. Ve Mes. Toksikoloji, Kayıt ve istatistik, Çevresel Gürültü, } \\
\text { Afet ve Acil Durum Org. İSG Yönetim Sistemleri, Kazaların Epidemiyolojisi, Taşıma } \\
\text { Ve Depolama, Elektrikle Çalışmalar Ve Basıçlı Sistemlerde İş Güvenliği, Arama } \\
\text { Kurtarma ve Yangın Bilgisi, Kimyasallar İş Tehlikeleri, Yönetim Sistemleri, Dönem } \\
\text { Uygulaması, Taşıma, Depolama ve Etiketleme, İş Güvenliği Eğitim Metotları, Mesleki } \\
\text { Proje, İşci Sağlığı }\end{array}$ & $35-42$ \\
\hline $\begin{array}{l}\text { DESTEK- } \\
\text { ALAN } \\
\text { TAKVIYE }\end{array}$ & $\begin{array}{l}\text { Mesleki Sorumluluk ve Etik, Eleştirel Düşünme, Yaratıcılık ve Giriş̧imcilik, Kalite } \\
\text { Güvencesi ve Kalite Yönetim Sistemleri, Temel Bilgi Teknolojileri, İlk Yardım, } \\
\text { Meslek Hastalıkları ve İşçi Sağlığı, İşsağlığı İlkeleri, İnsan Anatomisi ve Fizyolojisi, } \\
\text { Tıbbi Terminoloji, Halk ve Çevre Sağlığı, İşyeri Sağlık Gözetimi, Meslek Etiği, } \\
\text { İletişim, Protokol Bilgisi, Sağlık yönetimi, İş sağlığı ve meslek hastalıkları, } \\
\text { Endüstriyel Hijyen, Küresel farkındalık ve Güvenlik Kültürü, İSG’de Ödenek ve } \\
\text { tazminatlar, Çalışma psikolojisi, Teknolojinin Bilimsel İlkeleri, İşçi Sağlığı, Toplam } \\
\text { Verimli Bakım, }\end{array}$ & $21-26$ \\
\hline DİĞER- & Genel Kimya, Matematik, İstatistik, Fizik, & $4-12$ \\
\hline
\end{tabular}

Eğitime ve öğretime hazır bulunuşluk ve öğrenci bilgi alt yapısı ve yeterliliği gözetilmeksizin lisans, Y.lisans, doktora düzeyinde ders seçimlerinin yapıldığı, mesleki alan derslerinin konu düzeyinde ders olarak çeşitlendirildiği, İSGT/ İGU'ların görev, yetki ve sorumlulukları ile örtüşmeyecek, gereksiz, mesleki açıdan faydalanılmayacak kredi/AKTS doldurma amaçlı bazı derslerin programlarda yer verildiği görülmektedir.

Diğer bir sorun ise, ders yükünün fazla olmasıdır. Genel olarak, her bir dönemde ortalama 9-11 ders verilmekte ve bu husus derslerin tam olarak öğrenilememesi ya da uygulamaya dönüştürülememesine neden olmaktadır.

Tablo-7. Dönemsel ortalama ders yüklenme durumu

\begin{tabular}{|c|c|c|c|c|c|}
\hline Dönem & Üni-1 & Üni-2 & Üni-3 & Üni-4 & Üni-5 \\
\hline 1-Güz & 11 & 11 & 9 & 10 & 10 \\
\hline 2-Bahar & 11 & 11 & 11 & 10 & 11 \\
\hline 3-Güz & 10 & 7 & 10 & 11 & 9 \\
\hline 4-Bahar & 5 & 7 & 9 & 10 & 10 \\
\hline Toplam & $\mathbf{3 7}$ & $\mathbf{3 6}$ & $\mathbf{3 9}$ & $\mathbf{4 1}$ & $\mathbf{4 0}$ \\
\hline
\end{tabular}

İş sağlığı ve güvenliği programlarında, her üniversite kendi belirlediği bir program sunmaktadır ve her program bir birinden farklı bir içeriğe sahiptir. Bu durum, ortak bir öğretim planı uygulanamamasına neden olmaktadır. Bu durumun sebeplerinden birisi, dersi veren akademisyenlerin uzman oldukları alanı ders programlarına yansıtması veya akademisyen alanına göre ders düzenlemesi olarak belirtilebilir.

Ders programlarının incelenmesi ve irdelenmesi kapsamında ortaya çıkan bir diğer problem ise, eğitimlerin ağırlıklı olarak teorik olarak düzenlenmesidir. İş sağlığı ve güvenliği mutlaka pratik bir bilgi ile öğrencilere aktarılmalıdır. Bundan dolayı, ders programının pratik eğitime göre tekrar şekillendirilmesinin uygun olacağı değerlendirilmektedir. 


\section{Sorun-4. Öğretim Elemanı Açı̆̆ı;}

Meslek yüksekokullarının konum, kuruluş, kadro, akademik personel yetersizliği, laboratuvar, atölye, doküman ve öğrenci sayısı gibi ciddi ve önemli niteliksel ve niceliksel sorunları bulunmaktadır.

$\mathrm{Bu}$ doğrultuda iş sağlığı ve güvenliği eğitiminde de önemli sorunlardan biri de öğretim elemanı açı̆̆ olup bu durum, iş sağlığı ve güvenliği bölüm/ programlarında yürütülen eğitim için büyük bir sorun teşkil etmektedir. Bu durum, sektörün ihtiyacı olan nitelikli iş sağlığı ve güvenliği uzmanı yetiştirilememesine neden olmaktadır.

Bazı meslek yüksekokullarında kadroya atanmış öğretim elemanı bulunmaması, derslerin yürütülmesinde görülen zorluk ve dersin açıkta birakılmaması düşüncesiyle kamu görevlilerinden yararlanma cihetine gidildiği görülmektedir. İlgisiz alanlardan mezun akademisyenlerin, iş sağlığı ve güvenliği programlarına atanması veya görevlendirilmesi yöntemi en sık görülen yöntemlerden biri olarak yaşanmaktadır. Saha deneyimi bulunmayan akademisyenlerin, teorik ve pratik bilgilerinin yetersiz oluşu, özelikle uygulama ve ders pratiklerinde ciddi zaaflara yolaçmaktadır.

Bir diğer husus ise, iş sağlığı ve güvenliği bölümlerinin öğretim elemanı eksikliğine rağmen açılmaya devam etmesidir. Bu durum, eğitim kalitesini düşürmekte ve de sektöre nitelikli uzman sağlanamamasına yol açmaktadır.

\section{Sorun-5. Laboratuvar, Atölye Eksikliği;}

İş sağ lığı ve güvenliği eğitimindeki bir diğer sorun ise, üniversitelerin iş sağlığı ve güvenliğine yönelik teknik alt yapılarının yetersiz olması ve teknik donanımların eksik olmasıdır. Üniversiteler, iş sağlığı ve güvenliği programları açarken mutlaka eğitimin gereksinimlerine göre teknik donanımlarını ve de laboratuvarlarını tamamlamaları gerekmektedir. Özellikle fonksiyonel iş güvenliğinin en önemli parçası uygulamalar olup, sahada yaşanan sorunları gidermek ve uygun değer fayda sağlamak için bilinçli ve doğru yaklaşım önemlidir

Ders programları incelendiğinde, İSG 'nin nihai hedef ve öncelikli amacını sağlayacak şekilde düzenlenmediği, iş sağlı̆̆ ve güvenliği konuları dışında, alan ile ilgisi olmayan, mesleki açıdan destek veya gelişimi sağlayıcı özelliği bulunmayan bazı derslerin de verilmekte olduğu görülmektedir. Özellikle verilen derslerin içeriğinin iş sağlığı ve güvenliği eğitimiyle birebir örtüşmediği de görülmektedir.

\section{3- İS SAĞLIĞI VE GÜVENLİĞi LİSANS EĞiTiMì:}

Ülkemizde verilen iş sağlı̆̆ı ve güvenliği lisans eğitimi ile ilgili bilgiler tablo 8'de gösterilmiştir. Toplam 11 üniversitede (7 si devlet,4 vakıf) Sağlık Bilimleri Fakültelerine bağlı İSG Bölümleri açılmıştır.

Tablo -8. Lisans Programları Verilen Üniversite ve Fakülteler

\begin{tabular}{|l|l|l|l|}
\hline Üniversite & Sayıs1 & Fakülte & Yeri \\
\hline Devlet & 7 & Sağlık Bilimleri & $\begin{array}{l}\text { Bingöl, Uşak, Gümüşhane, Siirt } \\
\text { Sinop, Çanakkale, Yozgat }\end{array}$ \\
\hline Vakıf & 4 & Sağlık bilimleri & İstanbul (4) \\
\hline
\end{tabular}

Üniversitelerin Lisans kontenjanları tablo'9'de gösterilmiştir.

Tablo -9. Lisans Kontenjanlart

\begin{tabular}{|l|l|l|l|l|}
\hline Yıllar & $\begin{array}{l}\text { 1.Öğretim Öğrenci } \\
\text { Sayısı }\end{array}$ & $\begin{array}{l}\text { 2.Öğretim Öğrenci } \\
\text { Sayısı }\end{array}$ & $\begin{array}{l}\text { Toplam } \\
\text { Sayısı }\end{array}$ & Öğrenci \\
\hline 2016 & 368 & 196 & 564 \\
\hline 2017 & 592 & 114 & 706 \\
\hline 2018 & 612 & 98 & 710 \\
\hline
\end{tabular}

Üniversitelerin Sağlık Bilimleri Fakültelerine Bağlı İSG Bölümlerinin Ders programları incelendiğinde, iş sağlığı ve güvenliği konusunda mesleki yeterlilik ve alansal konu zenginliği açısından kapsamlı derslerin verildiğini görmekteyiz. Özellikle İSG'nin temel konuları olarak kabul edilen dersler başta olmak üzere (ISG Giriş, İş Kazaları, Meslek Hastalıkları, Afet ve Acil Durum Yönetimi, KKD, Risk yönetimi, ISSG Hukuku vb.) İş Güvenliği Uzmanlığı açısından önemli görülen mesleki açıdan takviye ve destek dersleri niteliğinde derslerin de alınması (Ekili İletişim, Diksiyon, İş Psikolojisi,Toplam Kalite Yönetimi,İnsan Kaynakları,Çalışma Hayatında Stres ve Yönetimi vb) program kalitesi ve yeterliliği açısından uygun değerlendirilmektedir. Aynı zamanda, 7 ve 8 nci akademik yarıyılda verilmek üzere planlanan uygulamaya yönelik derslerin ve saha çalışmalarının olması nitelik açısından program kalitesini artırmaktadır. 
İSG Lisans düzeyindeki eğitimin temel sorunu ise, eğitimi veren akademisyenlerin genelde iş sağllğı ve güvenliği alanında uzman olmamalarından kaynaklanmaktadır.

Ülkemizde iş sağlığı ve güvenliğine yönelik adımların geç atılması, bu konunun son yıllarda gündeme oturması ve çağdaş iş yaşamı norm ve standartlarının hukuki alt yapısı ve mevzuat düzenlemelerinin 2012 yıllından sonra ağırlıklı olarak tanzim edilmesi nedeniyle akademik alt yapı ve uzmanlaşma hususunda geç kalınmasına vesile olmuştur.

Geçmişin eksiklikleri bilimsel olarak bu alanda daha önceden yetişmiş nitelikli insan ve eğitmen kadrolarında zaafiyete neden olmuştur.

Ayrıca 4 yılllk lisans düzeyinde akademik eğitim ve öğretime tabi tutulan ve örgün eğitimden geçirilen ISG öğrencilerinin uzmanlık sınavına girebilmek için bakanlıkça yetki verilen eğitim kurumlarında eğitime tabi tutulması (90 saat uzaktan +90 saat örgün +40 saat uygulama) sistemle çelişen ve düzeltilmesi gereken bir durum olarak değerlendirilmektedir.

\section{5. İS SAĞLIĞI VE GÜVENLİ̆̈I YÜKSEK LISANS EĞİTiMİ}

\section{1. İsg Yüksek Lisans Programlari:}

Ülkemizde verilen iş sağlı̆̆ ve güvenliği yüksek lisans eğitimi kapsamında açılan programlar ve yürüten üniversiteler tablo 11'de gösterilmiştir. Tablo11'de görüldüğü üzere, iş sağlığı ve güvenliği yükssek lisans eğitimi, devlet ve vakıf üniversitelerinde tezli ve tezsiz olarak verilmektedir. Tezsiz yüksek lisans programının süresi 2 yarıyıl iken, tezli yüksek lisans programı ise 4 yarıyıldır. Tezsiz program $30 \mathrm{kredi}$, 10 dersden oluşmaktadır. Tezli program ise 21 kredi, 7 ders, 1 seminer dersi ve yüksek lisans tezinden oluşmaktadır. Örnek bir tezsiz yüksek lisans eğitimi programı tablo 8'de gösterilmiştir.

Tablo-11. ISG Alanında Yüksek Lisans Eğitimi Veren Üniversiteler

\begin{tabular}{|c|c|c|c|c|c|}
\hline Üniversite & Sayıs1 & Fen Bil. Ens. & $\begin{array}{c}\text { Sağllk Bil. } \\
\text { Ens. }\end{array}$ & $\begin{array}{c}\text { Sosyal Bil. } \\
\text { Ens. }\end{array}$ & $\begin{array}{c}\text { Halk Sağlı̆̆ } \\
\text { Ens. }\end{array}$ \\
\hline Devlet & 27 & 18 & 6 & 2 & 1 \\
\hline Vakıf & 17 & 11 & 6 & - & - \\
\hline Toplam & $\mathbf{4 4}$ & $\mathbf{2 9}$ & $\mathbf{1 2}$ & $\mathbf{2}$ & $\mathbf{1}$ \\
\hline
\end{tabular}

Lisansüstü Eğitim amacıyla açılan Fen Bilimleri, Sağlık Bilimleri, Halk Sağlığı, Sosyal Bilimler ve Lisansüstü Eğitim Enstitülerine bağlı olarak eğitim veren Tezli/Tezsiz toplam 84 İş Sağlı̆̆ı ve Güvenliği programı yer almaktadır. Bunlardan 40 program tezli iken 44 program tezsiz yüksek lisans olarak eğitimine devam etmektedir. Halk Sağlığı Enstitüsü bünyesinde 1 program yer alırken, Sosyal Bilimeler Enstitüsü bünyesinde Tezli/tezsiz İş Sağlığ ve Güvenliği için 2 program, Fen Bilimleri Enstitüsü bünyesinde 29, Sağllk Bilimleri Enstitüsü bünyesinde 12 program yer almaktadır.

Tezli ve Tezsiz İș Sağlı̆̆ı ve Güvenliği Yükseklisans programlarının bulunduğu üniversitelerin yer aldığı coğrafi bölgeler göre dağılımı incelendiğinde Marmara Bölgesi ilk sırada yer almaktadır. Toplamda Marmara Bölgesi için 21 Tezli program yer alırken 20 Tezsiz program toplamda 39 program ile ilk sıradadır. Daha sonra sırasıyla İç Anadolu Bölgesinde 9 program (7 Tezli- 6 Tezsiz), Ege Bölgesinde 4 program (4 tezli- 4 Tezsiz), Akdeniz 5 program, Karadeniz Bölgesi 4 (4 Tezli-3 Tezsiz) program ile takip etmektedir.

Açılan yüksek lisans programlarına talep durumu incelendiğinde sayısal ve bölgesel açıdan yeterli olarak değerlendirilmektedir.

\subsection{Yüksek lisans eğitim programlarının yeterliliği ve niteliği:}

Ülkemizde İSG alanında Yüksek lisans eğitim programlarının yeterliliği ve niteliği kapsamında Tezli/ Tezsiz programların (Karadeniz Teknik Üni, Bursa Teknik Üniversitesi, Başkent Üniversitesi, Çankaya Üni) incelenmesi sonucunda, programın akademik açıdan yeterli olduğu, akademik kriterleri karşıladığ 1 ve İSG'nin temel ve önemli konularına yer verildiği görülmektedir. Ancak seçmeli dersler ile öğrencilerin istedikleri alanda uzmanlaşmalarına olanak sağlanmaya kısmen imkan tanınmakta olup, bu açıdan yeterli görülmemektedir.

Tezli/Tezsiz yüksek lisans programları hazırlanırken bölgesel imkan ve yetenekler, endüstriyel koşullar, iş gücü ve işci hareketleri, çalışma yaşamının özellikleri, sektörel ihtiyaçlar, beklentiler ve eğitim ihtiyaçları gözetilerek düzenleme yapılmalıdır. Uzmanlaşmaya yönelik alt uzmanlık alanları kapsamında düzenlemeler yapılmalıdır. Bilinmesi zorunlu temel ve genel konuların yanında üniversitelerin konuşlu bulunduğu coğrafi bölgeler ve iş koşulları gözetilerek alt uzmanlık alan dersleri planlanmalıdır. (maden, makine, inşaat, gıda, tekstil, tarım, turizm, kimya, petrol, vb.) 
Eğitimlerde görülen en önemli eksikliklerin başında deneyimli, saha tecrübesi de olan uzman akademisyen ihtiyacı olup, atölye ve laboratuvar eksiklerinin bulunmasıda eğitim kalitesini etkilemektedir.

Bakanlık, YÖK ve üniversiteler uzmanlarından ve sektör temsilcilerinden oluşacak bir çalışma grubu tarafindan yüksek lisans eğitinmlerinin ele alınarak, sektörün ihtiyaçları doğrultusunda ders programlarının tekrardan değerlendirilmesine ihtiyaç duyulmaktadır.

\section{3. İş Sağlığı ve Güvenliği Eğitimlerinin bazı yabancı ülkelerde uygulanan benzeri programlarala Karşılaştırılması;}

Tablo-12. Yüksek Lisans Programları ders( Zorunlu-Seçmeli) karşılaştırma durum çizelgesi

\begin{tabular}{|c|c|c|}
\hline Üniversite & Zorunlu dersler & Seçmeli dersler \\
\hline $\begin{array}{l}\text { Karadeniz } \\
\text { Teknik Üni. } \\
\text { Y.Lisans } \\
\text { Prog. }\end{array}$ & $\begin{array}{l}\text { Ergonomi, Temel İş Güvenliği Önlemleri, Risk } \\
\text { Yönetimi, Araştırma Projesi( } 4 \text { zorunlu ders) }\end{array}$ & $\begin{array}{l}\text { Çevre Kirliliği ve Kontrolü, İş Güvenliği } \\
\text { Süreçleri, Tehlikeli Madde ve Atık } \\
\text { Yönetimi, Acil Durum Yönetimi, İş } \\
\text { Güvenliği Ekipman ve Donanımları, } \\
\text { Maden Sektöründe İş Güvenliği, } \\
\text { Elektrik Güç Sistemlerinde İş Güvenliği, } \\
\text { Hizmet Sistemlerinde İş Güvenliği, } \\
\text { Yangın ve Yangın Güvenliği, } \\
\text { Gürültü Kontrolü, İş ve İşçi Sağlığı, Acil } \\
\text { Durumlar ve İlk Yardım, İş Hukuku } \\
\text { Meslek Hastalıları ( } 7 \text { seçmeli ders) }\end{array}$ \\
\hline $\begin{array}{l}\text { ABD } \\
\text { Columbia } \\
\text { Southern Üni. } \\
\text { İSG Y.Lisans } \\
\text { Prog. }\end{array}$ & $\begin{array}{l}\text { İSG temelleri, Tehlikeli Madde Yönetimi } \\
\text { İnşaat Güvenliği, Hukuki Boyut, Yangın } \\
\text { Önlenmesi ( } 5 \text { Zorunlu ders) }\end{array}$ & $\begin{array}{l}\text { Yangın Davranış İlkeleri } \\
\text { İtfaiye Emniyet Görevlisi, } \\
\text { Yangın Önleme Organizasyonu, } \\
\text { Çevre Hukuku, Çevre Bilim } \\
\text { Değerlendirilmesi, Hava Kalitesi, Atık } \\
\text { Yönetimi, Tehlikeli Atık Yönetimi ( } 8 \\
\text { Seçmeli derrs) }\end{array}$ \\
\hline $\begin{array}{l}\text { KANADA- } \\
\text { Kanada- } \\
\text { Munchon } \\
\text { Üni, ISG } \\
\text { Yüksek } \\
\text { Lisans } \\
\text { program1 } \\
\end{array}$ & $\begin{array}{l}\text { İ̀s Sağlığı ve Güvenliği, Kanunlar, yönetmelikler, } \\
\text { paydaşlar, Riskleri Önleme, Endüstriyel } \\
\text { toksikoloji, Güvenlik-Iş güvenliği, ölçüm ve } \\
\text { analiz, önleme ve koruma programları( } 7 \text { zorunlu } \\
\text { ders) }\end{array}$ & $\begin{array}{l}\text { Ergonomi Tanıtımı, Endüstriyel Hijyen } \\
\text { (Sağlıklı Uyg),İş Güvenliği Yönetimi } \\
\text { Şirket: Yönetim, Güvenlik, iş sağlığı ve } \\
\text { güvenliğinde doğrulama programları ( } 4 \\
\text { seçmeli ders) }\end{array}$ \\
\hline $\begin{array}{l}\text { Bursa Tek. } \\
\text { Üni. ISG. } \\
\text { Y.Lisans } \\
\text { Prog. }\end{array}$ & $\begin{array}{l}\text { Risk Yönetimi, Dönem Projesi } \\
\text { Ergonomi, Temel İş Güvenliği Önlemleri (4 } \\
\text { zorunlu ders- IsşS Sağlığl ve Güvenliği Hukuku ve } \\
\text { Mevzuatı zorunlu seçmeli) }\end{array}$ & $\begin{array}{l}\text { Elektrik İş Güvenliği ve Mühendislik } \\
\text { Kontrolleri, Katı Atık Tesislerinde Risk } \\
\text { Faktörleri ve Risk Yönetimi, } \\
\text { Biyolojik Risk, Kimyasal Risk Etmenleri } \\
\text { Fiziksel Risk, İnşaat Sektöründe İş̧ } \\
\text { Güvenliği, Orman Ürünleri Sanayinde İş } \\
\text { Güvenliği, } \\
\text { İş Sağlığı ve Güvenliği Hukuku ve } \\
\text { Mevzuatı } \\
\text { İş Kazaları, Acil Durum ve Kriz Yön. } \\
\text { Üretim Tek İSG,,Gıda Sanayiinde İSG, } \\
\text { etal İşlerinde İSG,Radyasyon Sağlığı ve } \\
\text { Güvenliği, } \\
\text { Kimya Sektöründe İSG, Endüstriyel } \\
\text { Süreç Yönetiminde Kontrol Uygulamaları } \\
\text { ve Güvenlik Meslek Hastalıkları }\end{array}$ \\
\hline
\end{tabular}

ABD'deki İSG'nin amacı çalışanlara güvenli bir çalışma ortamı sağlayarak insan kaynaklarını korumaktır. ${ }^{7}$ İşverenler, çalışanlarını her türlü kazalardan kanunen uzak tutmak ile yükümlüdürler. ABD'de İSG uzmanı çalıştırmak kanunen zorunlu tutulmamakla beraber, işverenler kanunen çalş̧anlarını her türlü kazadan korumak ile yükümlüdürler. Bundan dolayı, işverenler İSG uzmanlarına ihtiyaç duymaktadırlar.

Ülkemizde, meslek yüksekokullarının iş sağlığı ve güvenliği bölümünden mezun olanlar, İSG teknikeri olmaktadırlar. İSG uzmanı olabilmek için ise, Aile, Çalışma ve Sosyal Hizmetler Bakanlığı'nın yetkilendirdiği eğitim merkezleri aracılı̆̆ıyla açılan toplam 220 saatlik eğitime $(90+90+40)$ tabi tutulmak zorundadırlar. Söz konusu eğitimin 90 saati uzaktan, 90 saati örgün ve 40 saati ise uygulamalı olarak düzenlenmek zorundadır. Bu Eğitimi başarı ile bitirmeleri gerekmektedir. ÖSYM tarafindan yapılan 
Uzmanlık sınavına katılıp başarılı olmaları halinde C uzmanlık sertifikası alabilmektedirler.ABD'de ise ön lisans veya endüstriyel güvenlik sertifkası ile İSG uzmanı olunabilmektedir. ABD'de İSG uzmanları belli başlı konularda uzmanlaşıp, sektöre bu şekilde dahil olmaktadırlar.

Öğretim programlarının karşılaştırılması için, Columbia Southern Üniversitesinin, iş sağlığı ve güvenliği programı aşagıdaki (Tablo-13) da, Kanada-Munchon Üniversitesi, İş Sağlığı ve Güvenliği Yüksek Lisans programı (Certıficat en sécurıté et hygıène au travall) (iş săglı̆̆ ve güvenliği sertifikası) tablo-14'da gösterilmiştir.

Kanada, ABD'de ve Türkiye'deki yüksek öğretim ders planlamasına bakıldığında, Türkiye'deki ders seçiminin temel olarak ABD'dekine benzerlik gösterdiği görülmektedir. Ancak, ABD'de çevre ile ilgili dersler de iş sağlığ 1 ve güvenliği eğitiminin bir parçasıdır. (21)

ABD'de iş sağllğ 1 ve güvenliği sadece iş yeri ile ilgili kavramları kapsamayıp, toplumun çevre ile olan ilişkisini de kapsamaktadır. Ülkemizdeki eğitimin önemli eksikliklerinden birisi, çevrenin İSG alanına dahil edilmemesinden veya çevresel faktörlerin eğitimlerde gözardı edilmesinden kaynaklanmaktadır. ${ }^{7}$

\section{6-SONUÇ VE ÖNERILER:}

\subsection{Sonuç olarak:}

Ülkemiz iş kazaları istatistikleri kapsamında, Avrupa ve dünya sıralamasında maalesef ilk sıralarda yer almaktadır. Özellikle ölümlü iş kazaları açısından Avrupa'da birinci dünyada ise üçüncü sıradadır.Küreselleşme ve neoliberal ekonomik politikalar sonucunda iş güvencesininim azalması,esnek çalışma biçimleri,çalışma koşullarının ağırlaşması,özelleştirme,örgütlülük ve sendikalaşma yetersizliği,taşeronlaşmanın yaygınlaştırılması,sosyal güvenlik ve güvenceden yoksun kayıt dışı işçilik,çocuk işçi çalıştırma,işverenlerin önlem almadaki isteksizliği ve yetersizliği,maliyet- etkinlik anlayışının olumsuz işlemesi,eğitim yetersizliği,işyeri denetim ve kontrol sistemlerindeki zafiyet,idaricezai yaptırımların yetersizliği, ülkemizde iş kazalarini ve meslek hastalıklarını artıran sebepler arasinda sayilabilir.

Gelişen ve değişen iş koşulları ve sektörel gelişmeler, yenilenebilir teknolojik ürünlerin önünü açmış ve demode olan teknolojinin yerini yeni nesil donanımlar almıştır.Söz konusu alanlara ,bilgi çağının imkânları ile robot ve uzay teknolojisi, benzetim ve sanal yaklaşımlar teknolojisi, bilişim dünyasının yeni imkânlar sunması ve sosyo-ekonomik, kültürel, eğitim alanındaki gelişmeler de eklenince etkin otomasyon, ınovasyon ve güncel teknoloji kullanımı işyerlerinin vazgeçilmez unsuru haline gelmiştir. Bu meyanda dünyada ve ülkemizde İş sağlı̆g 1 ve güvenliği giderek artan bir oranda önem kazanmaktadır. Yapılan tüm bilimsel incelemeler gösteriyor ki iş kazaları ve meslek hastalıklarının önlendiği veya minimum seviyeye çekildiği, sağlıklı ve güvenli çalışma ortamlarının oluşturulduğu ülkelerde veya küresel ölçekte büyük kurumsal firmalarda insana ve eğitime yapılan yatırım öne çıkmaktadır. Bu doğrultuda, en önemli kuvvet çarpanı eğitim olup, güvenlik kültürünün gelişmesi ve yerleşmesi açısından üniversteler önemli bir faktördür. Üniversitelerimizde ön lisans, lisans, yüksek lisans, doktora düzeyinde öğretim programları açılmıştır. Açılan ve yürütülen İş sağlığı ve güvenliği programlarının temel sorunu, ilgili alanda akademisyen açığı ve buna bağlı gelişen eğitim kalitesi düşüklüğü ve uygulamaya yönelik pratik eğitim eksikliğidir.

İş sağlığı ve güvenliği temelde sağlık ve güvenlik olarak iki kısımdan oluşmaktadır. Bu bağlamda, iş sağlığı ve güvenliği eğitimi, hem sağlık açısından hem de güvenlik açısından düzenlenmelidir (4)

İş sağlı̆̆ 1 ve güvenliği eğitimi disiplinler arası bir eğitimdir. İnşaattan kimyaya, madenden mühendisliğe kadar birçok teknik disiplini içinde barındırmakla beraber, aynı zamanda tıbbi ve hukuki alanları da kapsamaktadır.(3) Bu durum, iş sağlı̆̆ı ve güvenliği eğitiminin uzun bir sürece yayılması gerektiğini göstermektedir. Eğitimin hem teorik kısmı hem de uygulamalı kısmı, bu içerik göz önünde bulundurularak hazırlanmalıdır.

Ülkemizde iş sağlığı ve güvenliği eğitimi ilk olarak 1996 yılında ön lisans olarak verilmeye başlanmıştır. Lisans düzeyinde ise 2012 yılında verilmeye başlanmıştır. Ancak nitelik olarak halen iş sağlığı ve güvenliği eğitimi sektörün ihtiyacını karşılamaktan uzakta ve aynı zamanda nicelik olarak da, eğitimin içeriği yeterli değildir.

Lisansüstü eğitiminde ise, son yıllarda hem devlet hem de vakıf üniversitelerinde tezli/tezsiz bölümler açılmaya başlanmıştır. Doktora eğitiminde ise, henüz istenen seviyeye ulaşılamadığı görülmektedir. (7) Ayrıca Önlisans düzeyinde Uzaktan öğretim yada açık öğretim proğrağramlarının 2015 yılından sonra çok fazla sayıda öğrenci alımı yaptığı tespit edilmiştir. Direk insan hayatıyla ilgili olan bu meslek kolunun uzaktan eğitim ile sadece ders notlarına çalışarak İş Güvenliği Uzmanı olan kişilere emanet edilen işyerleri isg çalışmalarını verimli ve etkin olarak sürdürmeleri mümkün görülmemektedir. İnsan hayatıyla direkt bağlantılı çalışılan bu meslek gurubunun eğitimleri örgün ve uygulamalı yapılması zorunludur. $\mathrm{Bu}$ nedenle uzaktan veya açık öğretim şekliyle eğitim veren kurumların derhal kapatılmasının uygun olacağı düşünülmektedir. Bu konudaki diğer bir husus ön lisans mezunu kişilerin 
Aile, Çalışma ve Sosyal Hizmetler Bakanlığının ÖSYM aracılığıyla yaptırılan uzmanlık sınavlarda başarılı olması durumunda kademeli olarak zamanla A sınıfı uzman olabilmektedirler. Yine aynı şekilde bu meslekte doktora yapmış bir kişi de aynı sınava girerek yine A sınıfı uzman olabilmektedir. Konusuna akademik çalışma yapmış bir A sınıfı uzman ile ön lisans mezunu bir A sınıfı uzman kesinlikle aynı kategoride değerlendirilmeyecek yeni bir system düzenlemesine ihtiyaç olduğu da ortadadır.

Yurtdışında İş Sağlığı ve Güvenliği kapsamında verilen eğitimler ile ülkemizde verilen aynı kategorideki eğitimler karşılaştırıldığında, ülkemizde verilen programların halk ve çevre sağlığı konularını genelde kapsamadığı görülmektedir.

\section{2. Çözüm olarak öneriler;}

Üniversitelerimizin ihtiyaç duyduğu akademisyen açığı kapatılmalı, bu doğrulta İSG programlarında okuyan yüksek lisans öğrencilerin doktora programlarına teşvik edilmesi üzerinde önemle durulmalıdır. İş Sağlığı ve güvenliğinin bir bilim dalı olarak müstakil kürsüye dönüştürülmesi ve akademisyen kadrolanması yapılmalıdır.

Aynı zamanda, sektörün ihtiyaç duyduğu ISG uzmanları, daha pratik bir eğitim programına tabi tutulmalıdırlar.

YÖK Başkanlığında Aile, Çalışma ve Sosyal Hizmetler Bakanlığı, Üniversitelerden bu alanda çalışan akademisyenlerden ve sektör temsilcilerinden oluşturulacak özel bir çalışma grubu kurularak önlisans programlarından başlanarak ISG Programları standardizasyonu (ÇEP) sağlanmalıdır.

İş güvenliği uzmanları çalıştığı veya çalışılacak sektörler gözetilerek alt uzmanlık alanlarına (inşaat, maden, kimya, metal, tarım, tekstil, makina, elektrik, enerji vb) göre ilave eğitimden geçirilmelidir. Genel iş güvenliği uzmanlığı yanında çalışılan işyeri ve sektör gözetilerek alt uzmanlık eğitiminden geçirilmelidir. Alt uzmanlık eğitim sertifikası/ belgesi çalışma koşullarının önemli ve zorunlu bir belgesi niteliğine kavuşturulmalıdır.

Uzmanlık belgesinin alan iş güvenliği uzmanlarının mesleki körlük ve yetersizliklerini ortadan kaldıracak ilave bir değerlendirme sistemi kurulmalıdır. Örneğin; uzman olan kişilerin belgesini aldığı tarihten itibaren 3- 5 y1l sonunda (pelirli bir periyotta) mesleki ehliyet ve bilgi altyapısını ölçen değerlendirme sınavları yapılarak uzmanlık tescil belgesini alanlar bu alanda çalışmaya devam edebilecekleri bir sistem kurgulanmalıdır.

\section{KAYNAKLAR}

1.ŞIŞMAN,M.,Örgütler ve Kültürler,1.b., Pegem yayıncılık,Ankara,2002

2. DURSUN,S.,İş Güvenliği Kültürü,Beta Yayınları,İstanbul,2012,

3. GEREK, N.,İ ş sağlığı ve Güvenliği, Anadolu Üniversitesi yayını no:2236, Eskişehir,Temmuz2011, S;16

4. GEREK,N.,İ ş sağlı̆̆ı ve Güvenliği, Anadolu Üniversitesi yayını no:2236, Eskişehir,Temmuz2011, S;17

5. ALTIEL,H., İşçi Sağlığı ve İş Güvenliği, Detay yayıncılık, Gaziantep,Subat-2015,

6. ŞAHINGÖZ AKAR,S., ŞIK A., Konaklama ve Beslenme İşletmelerinde İş Sağlığı ve Güvenliği, Detay Yayıncılık,Ankara-2015,sf;13-14

7. http://www.sgk.gov.tr/wps/portal/sgk/tr/kurumsal/istatistik/sgk_istatistik_yilliklari ( Erişim Tarihi: 20.02.2019)

8. https://www.yenisafak.com >Ekonomi Haberleri ( Erişim Tarihi:20.02.2019)

9. https://guvencosgb.com/is-kazalarinda-turkiye-avrupa-birincisi-dunya-ucuncusu/ (Erişim Tarihi: 20.02.2019)

10. CEYLAN H., "İmalat Sistemlerindeki İş Kazalarının Tahmini İçin Ağırlıklandırılmış Ortalamalardan Sapma Tekniği’, Gazi Üniversitesi, Fen Bilimleri Enstitüsü, Yayınlanmamış Doktora Tezi, Ankara, 2000. 
11. 28648 sayılı,15. 05. 2013 tarihli "Çalışanların iş sağlığı ve güvenliği eğitimlerinin usul ve esasları hakkında yönetmelik',

12. SİVRIKAYA, O., "Türkiye'de Yükseköğretim Kurumlarında İş Sağlı̆ğ ve Güvenliği Eğitiminde Güncel Durum", Adana Bilim ve Teknoloji Üniversitesi, Mühendislik ve Doğa Bilimleri Fakültesi, Maden ve Cevher Hazırlama Mühendisliği Bölümü, Adana, Türkiye, 2016.

13. Yüksek Öğretim Kurumu https://yokatlas.yok.gov.tr/Ön lisans-program.php?b=30008, Erişim tarihi; 08.11.2018

14. Başkent Üniversitesi Bilgi Paketi, bilgi.baskent.edu.tr/ Erişim tarihi; 07.11.2018

15. Aile, Çalışma ve Sosyal Hizmetler Bakanlığı, Türkiye geneli İGU sayısal verileri Aralık,2018,

16. Pamukkale Üniversitesi, Eğitim Öğretim Bilgi Sistemi,ebs.pau.edu.tr Erişim tarihi; 08.11.2018

17. Kafkas Üniversitesi, Bilgi Paketi - https://obsyeni.kafkas.edu.tr/oibs/bologna Erişim tarihi; 09.11.2018

18. İstanbul Arel Üniversitesi AKTS bilgi paketi, https://www.arel.edu.tr/eobstest, Erişim tarihi; 09.11.2018

19. Ondokuz Mayıs Üniversitesi Bilgi Paketi - OMÜ, ebs.omu.edu.tr/ebs/index.php?dil=tr erişim tarihi; 09.11.2018

20. .28339 sayılı, 30.06.2012 tarihli resmi gazete yayımlanan 6331 Sayılı iş sağlığ1 ve güvenliği kanunu,

21. 28512 sayılı 29. 12. 2012 tarihli resmi gazetede yayımlanan İş Güvenliği Uzmanlarının Görev, Yetki, Sorumluluk ve Eğitimleri Hakkında Yönetmelik,

22. CEYLAN, H., “Türkiye'deki İş Sağlığı ve Güvenliği Eğitimi Sorunlar ve Çözüm Önerileri”, 2012.

23. YEŞİL, Y., ÇALIŞ, Ö., "İş Sağlığı ve Güvenliği Eğitiminde Ön lisans Programları: Türkiye'deki Uygulama ve ABD’deki Uygulama ile Karşılaştırılması", Süleyman Demirel Üniversitesi, İktisadi ve İdari Bilimler Fakülte Dergisi, 2016, c21, s4, 1173-1189.

24. Columbia Southern University, Occupational Safethy \& Health.http://www.columbiasautthern. edu.tr/occupational-safety/as-osh erişim tarihi; 30.11.2018

25. fbe.btu.edu.tr/index.php?sid=6960İş Sağlı̆̆1 ve Güvenliği Yüksek Lisans ders (Erişim 24 Mart 2019) 